\title{
Hibridização in situ com sonda não-radioativa para mRNA: principios e aplicações em patologia
}

\section{In situ hybridization with non-radioactive riboprobes: principles and applications in pathology}

Maria das Graças da Silva-Valenzuela'; Fernanda Campos S. Almeida²; Luciana Fasanella Matizonkas-Antonio²; Tatiana Nayara Libório²; Thais Acquafreda²; Claudia Cazal'; Alberto Ferraz ${ }^{3}$; Fábio Daumas Nunes ${ }^{4}$

\section{unitermos resumo}

A técnica de hibridização in situ (ISH) tem sido usada para identificar mRNA (ou DNA) em amostras de RNA mensageiro tecido de material humano e animal. Embora uma série de protocolos para essa técnica seja utilizada, as descrições não são bem detalhadas. O objetivo deste trabalho é descrever a reação de hibridizaPatologia ção in situ em tecido fresco e sua aplicação em patologia, tornando mais compreensível essa técnica tão importante, que possibilita observar a localização tecidual e a expressão temporal e espacial dos transcritos de um determinado gene (mRNA). Resultados de reações com as ribossondas PITX1, SHH e WNT-5A, realizadas em amostras de tecido congelado, são apresentados.
\end{abstract}

\section{abstract}

In situ hybridization (ISH) has been used to identify mRNA (or DNA) in fresh tissue samples of humans and animals. Several protocols describing this technique are available, although its description is not usually detailed enough. The present work describes in situ hybridization reaction on fresh tissue in a way to make understandable this important technique, which allows verifying the cellular localization, and the spatial and temporal expression, of gene transcripts (mRNA). Results with PITX1, TGIF, SHH and WNT-5A riboprobes, in fresh tissue samples, are presented.

\section{key words}

In situ hybridization

Messenger RNA

Pathology

\section{Introdução}

Embora tenha sido descrita pela primeira vez em $1969^{(7)}$, somente na década de 80 a reação de hibridização in situ (ISH) despertou o interesse da área médica em geral, a partir de trabalhos publicados na literatura considerando-a uma ferramenta importante para a melhoria da qualidade dos diagnósticos. O grande atrativo da reação ISH é a possibilidade de localizar com precisão no tecido, parafinado ou congelado, um gene específico ou seus transcritos. Outras técnicas de biologia molecular, como a reação em cadeia da polimerase (PCR), permitem a detecção de mRNA ou DNA extraídos de tecidos, mas não permitem observar a distribuição dos transcritos ou DNA em um tipo de população celular ou em áreas

1. Pesquisadora do Programa para Contratação de Técnicos de Nível Superior (PROCONTES), disciplina de Patologia Bucal da Faculdade de Odontologia da Universidade de São Paulo (FOUSP).

2. Pós-graduandos em Patologia Bucal, disciplina de Patologia Bucal da FOUSP.

3. Professor-titular da disciplina de Cabeça e Pescoço da Faculdade de Medicina da Universidade de São Paulo (FMUSP).

4. Professor-associado da Disciplina de Patologia Bucal da FOUSP.

Trabalho realizado no Departamento de Estomatologia, Disciplina de Patologia Bucal da FOUSP. 
de tecidos adultos ou em desenvolvimento. A visualização do padrão de expressão de um gene é interessante para a análise da sua função, e mesmo como marcador da diferenciação celular ou do estímulo fisiológico recebido pelas células ${ }^{(25)}$. Além disso, a técnica permite associar a presença de DNA ou mRNA de microorganismos com a morfologia, ou mesmo relacionar a presença de genes e seus transcritos com os processos patológicos.

Variações do método foram descritas no sentido de aprimorar a resposta do sinal obtido ${ }^{(12)}$, principalmente em relação a sensibilidade e especificidade, preparação das sondas ${ }^{(6,15,17)}$ e amplificação do sinal(5, 16), contribuindo muito para o aperfeiçoamento da técnica ao longo dos anos. Em 1989, descreveu-se o uso simultâneo da reação de ISH com a imuno-histoquímica ${ }^{(27)}$. Isso ampliou o campo de aplicação da reação de hibridização in situ, uma vez que torna possível identificar dois diferentes RNAs mensageiros ou um gene e seu produto ${ }^{(21)}$. Essa combinação da ISH com a imuno-histoquímica é particularmente interessante para a patologia, principalmente em se considerando a recente popularidade da última.

Atualmente, os vários projetos genoma nacionais e internacionais disponibilizaram uma série de genes identificados em seres humanos e animais ${ }^{(10)}$. A técnica é especialmente importante no caso de genes novos, pois permite localizar transcritos desses genes, já que anticorpos para as proteínas específicas ainda não estariam comercialmente disponíveis.

Neste trabalho abordaremos os princípios da técnica de ISH aplicados a tecidos congelados e fixados em paraformaldeído. Não é intenção deste artigo esgotar os vários aspectos técnicos da metodologia, muitos deles descritos em livros-texto. Mostraremos resultados obtidos com sondas de mRNA em carcinomas epidermóides de boca e tecidos embrionários de camundongos, especialmente interessantes em estudos de processos patológicos e como exemplo da diversidade de aplicação da técnica.

\section{Reação de hibridização in situ}

A reação de hibridização in situ é definida como o pareamento dos nucleotídeos contidos em fitas complementares de DNA e RNA através de ligações hidrogênio ${ }^{(9)}$ numa lâmina de vidro, sendo possível parear DNA-DNA (combinações de pares de base A-T e G-C), DNA-RNA (combinações de pares de base A-T, G-C e A-U) e RNA-RNA (combinações de pares de base $\mathrm{A}-\mathrm{U}$ e $\mathrm{G}-\mathrm{C}$ ) entre cadeias complementares.
O sucesso dessa reação pode ser garantido estabelecendo-se critérios rigorosos relativos a preservação do tecido, preparação de sonda e reagentes e otimização das condições da reação. Essa técnica é muito importante para detectar RNA mensageiro em qualquer tecido. Entretanto, ao contrário do DNA, que é uma molécula estável e de fácil preservação, o RNA é degradado facilmente pela ação das ribonucleases, enzimas mais conhecidas como RNases, que são termoestáveis e resistentes a quase todos os tipos de superfície.

\section{Preservação do tecido}

O tecido destinado à reação ISH deve receber tratamento prévio e específico de fixação e pré-hibridização para garantir a boa preservação da sua morfologia e a eficiente hibridização da sonda. Existem várias possibilidades de fixadores, com diferentes tempos de fixação, porém o paraformaldeído $4 \%$ é o mais utilizado por conservar bem o tecido sem alterar a sua estrutura morfológica ${ }^{(2,19,20,22)}$. Inicialmente, o tecido obtido de biópsia, livre de contaminação, deve ser imediatamente fixado por imersão em uma solução estéril de paraformaldeído 4\% por pelo menos 18 horas, sendo que grandes fragmentos de tecido devem ser evitados. Quando se trabalha com RNA, recomenda-se que o tecido seja criteriosamente manipulado sob condições estéreis e livres de ribonucleases. Após a fixação com paraformaldeído, tratamento adicional com sacarose $30 \%$, para desidratação, deve ser realizado. A seguir o tecido deve ser incluído em um polímero inerte (ex.: Tissue-Tek $^{\circledR}$ O.C.T., Sakura Finetek, EUA), montado em um criomolde, e congelado a $-80^{\circ} \mathrm{C}$ por tempo indeterminado. $\mathrm{O}$ tecido assim congelado é, então, submetido a cortes em criostato, onde as finas secções obtidas $(\sim 10 \mu \mathrm{m})$ são recolhidas sobre lâminas tratadas com 3-aminopropil-trietoxi-silano (Sigma Chemical Co, St Louis, MO USA).

\section{Preparação da ribossonda}

A escolha e a síntese da sonda para a reação de ISH são duas das partes principais do planejamento da reação. Diferentes sondas podem ser utilizadas para ISH, como DNA, CDNA, cRNA e de oligonucleotídeos, que podem ser inclusive obtidas comercialmente. As sondas de RNA estão entre as mais utilizadas e são as que abordaremos neste artigo.

As sondas de DNA e RNA utilizadas na reação de ISH devem ser inicialmente marcadas com: a) radioisótopos, como ${ }^{3} \mathrm{H},{ }^{35} \mathrm{~S},{ }^{125} \mathrm{I},{ }^{32} \mathrm{P} \mathrm{e}{ }^{33} \mathrm{P}$; ou b) materiais não-radioativos, 
como biotina, digoxigenina ou fosfatase alcalina. Apesar de a sonda radioativa ser mais sensível, a marcação nãoradioativa apresenta a vantagem de ter maior estabilidade e melhor resolução(12). Essa marcação, quando para ribossondas, se faz geralmente a partir de reação de transcrição in vitro, utilizando-se muitas vezes nick translation, um procedimento para introdução de nucleotídeos marcados numa molécula de ácido nucléico.

As sondas de fita simples são mais eficientes devido a sua maior capacidade de pareamento. As sondas de RNA, ou ribossondas, podem ser preparadas a partir de reação de transcrição in vitro, usando seqüências de CDNA como molde, as quais serão subclonadas em um vetor próprio para transcrição ${ }^{(20)}$. Vetores são fragmentos de DNA que se replicam em células vivas e são construídos para carregar um fragmento exógeno de DNA ou cDNA.

Os vetores de clonagem apresentam várias regiões específicas, entre elas duas regiões contendo promotores de RNA polimerase, onde se inicia a reação de transcrição in vitro; um sítio de clonagem múltipla (MCS) e um gene de resistência a antibiótico. O gene (ou transcrito) a ser estudado pode ser obtido, por exemplo, por amplificação pela PCR. Esse fragmento de ácido nucléico (ou inserto) é inserido na região MCS do vetor para transcrição, utilizando-se para isso um protocolo ou kit de clonagem (por exemplo, TOPO TA Cloning Kit, Invitrogen, Carlsbad, CA, USA). A molécula de DNA recombinante obtida é então inserida numa célula hospedeira compatível (transformação), purificada e linearizada com as endonucleases (enzimas) de restrição adequadas ${ }^{(8)}$. Após a linearização, a sonda de RNA pode ser obtida por transcrição in vitro utilizando-se a RNA polimerase adequada e os nucleotídeos ATP, CTP, GTP e UTP, além da UTP marcada com digoxigenina, por exemplo. Portanto, a preparação da sonda tem quatro etapas importantes: 1) escolha do vetor; 2) amplificação do gene e subclonagem; 3) linearização do DNA recombinante; 4) obtenção do transcrito (Figura 1).

Cox et al. ${ }^{(6)}$ descreveram que o sistema vetor-transcrição in vitro origina sondas de RNA de fita simples e aumenta a eficiência da hibridização. Atualmente, esse é o sistema mais usado para preparações de sondas de fita simples para as reações de ISH.

Na célula, o mRNA é senso, portanto sondas anti-senso devem ser utilizadas para detectá-lo. Dessa maneira, durante a etapa de transcrição devem-se obter sondas anti-senso $(\alpha)$, que irão parear com o RNA em estudo, e sondas senso (s), que servirão como controle negativo. As enzimas de polimerização para RNA (RNA polimerases) bacteriófago T3 (T3),

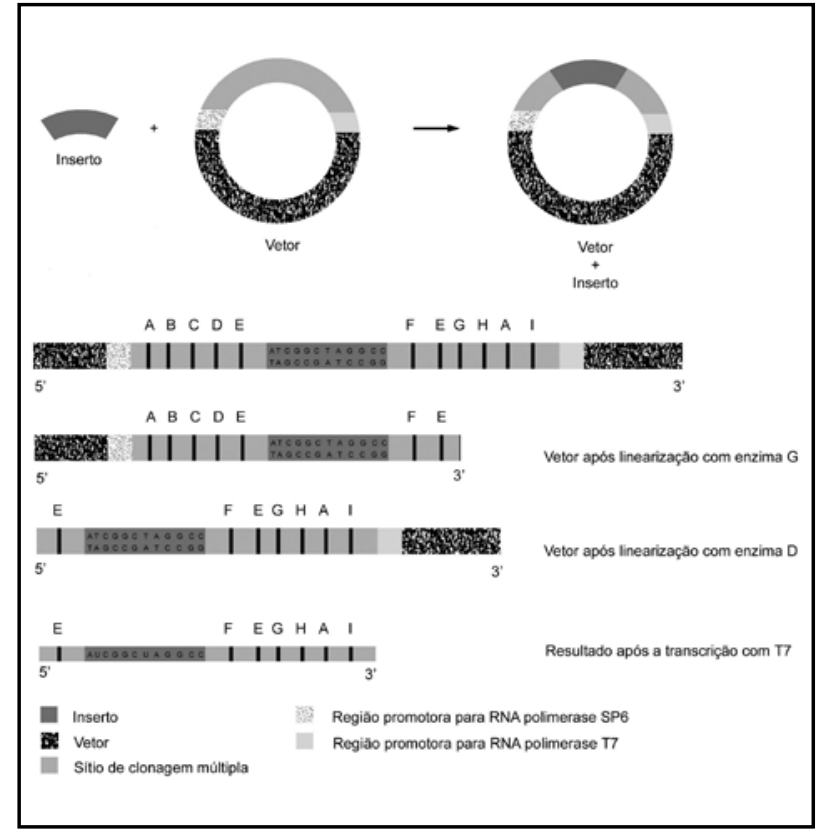

Figura 1 - Diagrama esquematizando as principais etapas de preparação da sonda. O DNA-alvo ou inserto, numa primeira etapa, é inserido no MCS de um vetor hipotético com uma região MCS e duas regiões promotoras para as RNAs polimerases Sp6 e T7. 0 vetor com o inserto (recombinante) é linearizado no MCS, utilizando uma enzima de restrição. Observe, no diagrama, como é possivel relacionar a enzima de restrição com a enzima de polimerização e a orientação anti-senso e senso. Observe, por exemplo, que se a enzima hipotética E for escolhida como enzima de restrição não restarão sítios promotores ligados ao inserto para proceder à reação de transcrição. Escolhendo-se a enzima hipotética $\mathrm{G}$, localizada do lado direito do inserto, restará um fragmento linearizado contendo a seqüencia do inserto e a seqüência promotora da enzima RNA polimerase, além de outras seqüências. Nesse caso, a enzima RNA polimerase escolhida deve ser Sp6 e a orientação da ribossonda será, por exemplo, anti-senso $(\alpha)$. Da mesma maneira, escolhendo-se a enzima $D$, localizada do lado esquerdo do inserto, restará um fragmento que conterá a seqüência do inserto e a seqüência promotora da enzima RNA polimerase T7, além de outras, e o sentido da orientação da ribossonda será senso (s)

bacteriófago T7 (T7) e Salmonella typhimurium (Sp6) são, geralmente, as mais utilizadas para orientação das seqüências. Com freqüência se utiliza vetor disponível comercialmente, o qual já traz, adjacentes à região de clonagem múltipla, sítios promotores para as enzimas RNA polimerases. Assim, o promotor possibilita que vetores sejam usados para gerar sondas de RNA (ribossondas) complementares às cadeias anti-senso e senso do DNA-alvo.

Embora esse seja um dos métodos mais utilizados para construção de sondas para uso em ISH, outros métodos estão disponíveis. Nakajima et al.(17) descreveram um tipo de sonda para hibridização in situ denominada HybridAT. Nesse caso a sonda consiste em uma região de hibridização e uma região que tem (AT) $)_{10}$ no terminal 3', e o método é considerado pelos autores mais sensível que aquele que utiliza uma ribossonda. Entretanto, todos os métodos são descritos como eficientes para tecido congelado. No caso de tecido parafinado, devido à ação das ribonucleases, pode-se 
combinar a ISH com um método de amplificação. Entre os sistemas de amplificação que podem ser utilizados ${ }^{(17)}$ temos um catalisador (CSA, do inglês catalyzed signal amplification) ou um tiramida (TSA, do inglês tyramide signal amplification). Esses sistemas são utilizados para amplificar o nível de detecção do sinal obtido tanto em imuno-histoquímica como em reações de hibridização in situ.

Existem vários fatores a serem considerados na seleção da sonda. Esses fatores incluem, por exemplo, especificidade, abundância do mRNA dentro da célula, quando é expresso, conservação da seqüência entre espécies (principalmente quando do estudo de microorganismos). O tamanho ótimo da sonda geralmente fica por volta de 200 a 500pb, para melhor penetração no tecido, embora sondas maiores possam ser confeccionadas.

Convém ressaltar que o cuidado com a manipulação de reagentes e materiais é fundamental. As ponteiras e os tubos cônicos utilizados devem ser estéreis e tratados com produto específico (por exemplo, RNase Away, Ambion, Austin, Texas, USA) para diminuir a ação das ribonucleases. Devem-se utilizar luvas e máscaras descartáveis para evitar qualquer risco de contaminação da reação pelo operador ${ }^{(3)}$.

\section{Eficiência e especificidade}

Os parâmetros eficiência e especificidade são muito importantes para a reação de ISH porque estão diretamente relacionados com a qualidade dos resultados obtidos. A eficiência está relacionada com a capacidade de pareamento entre o RNA mensageiro e a ribossonda, e a especificidade, à detecção apenas da seqüência-alvo. Nesse aspecto, as condições de estringência durante e após a reação são muito importantes. Estringência é definida como um conjunto de condições que interfere na associação das fitas de ácidos nucléicos. Fatores como as concentrações de formamida, sais e da sonda e a temperatura de hibridização(6) influenciam significativamente nas condições de estringência. A alta estabilidade térmica encontrada nos híbridos RNA-RNA em relação aos híbridos DNA-RNA e DNA-DNA favorece condições de alta estringência, e isso aumenta a especificidade da reação, ou seja, a probabilidade de a sonda hibridizar apenas com o RNA-alvo. Uma temperatura ótima de hibridização fica geralmente entre $15^{\circ}$ e $25^{\circ} \mathrm{C}$ abaixo da temperatura de fusão $\left(T_{m}\right)$. Existem várias fórmulas para calcular a $T_{m}$ na dependência do seu tamanho e do tipo de híbridos formados. Para ribossondas (híbridos de RNA-RNA), a seguinte fórmula pode ser usada: $\mathrm{T}_{\mathrm{m}}=78^{\circ} \mathrm{C}+16,6(\log 10[\mathrm{Na}+])+$ $0,7(\% \mathrm{G}+\mathrm{C})-0,35$ (\% formamida) - (500/l), onde [Na+] é dada segundo a concentração de tampão citrato de sódio (SSC) (Tabela), e Lé o comprimento da sonda em pares de base $(\mathrm{pb})$. Deve-se ter em mente que híbridos de RNA-RNA são geralmente $10^{\circ} \mathrm{C}-15^{\circ} \mathrm{C}$ mais estáveis e, portanto, são necessárias condições mais estringentes de hibridização e lavagem pós-hibridização.

A formamida, por suas características moleculares, facilita a remoção, após a hibridização, de sondas que permanecem como fita simples, diminuindo a reação inespecífica de fundo e, assim, aumentando a qualidade dos resultados.

\section{Detectando RNA mensageiro em tecido fresco}

O protocolo que descreveremos para ISH compreende, em síntese, três etapas distintas: a) hibridização propriamente dita, onde há o pareamento da sonda à seqüência-alvo; b) imuno-histoquímica ou reação antígeno/anticorpo para detecção da sonda; c) revelação com o cromógeno desejado. Essas três etapas consomem em média três dias de lavagens com tampões e incubações com reagentes específicos. Uma das etapas fundamentais é o pré-tratamento do tecido com proteinase $\mathrm{K}$, para aumentar a acessibilidade dos ácidos nucléicos após otimizar a concentração (geralmente entre 1 e $50 \mu \mathrm{g} / \mathrm{ml}$ ) e o tempo de tratamento (entre cinco e 30 minutos) na dependência de tipo de tecido, fixador, tempo de fixação, etc. As etapas principais são as seguintes: no primeiro dia, após descongelamento completo das lâminas, pós-fixar com paraformaldeído 4\% (Sigma, Alemanha); lavar três vezes, durante cinco minutos cada, com o tampão salino PBT $\left(0,1 \%\right.$ Tween $20,1 \times$ PBS $\left[10 \times\right.$ PBS $=0,01 \mathrm{M} \mathrm{KH}_{2} \mathrm{PO}_{4}$; $0,1 \mathrm{M} \mathrm{Na}_{2} \mathrm{HPO}_{4} ; 1,37 \mathrm{M} \mathrm{NaCl} ; 0,027 \mathrm{M} \mathrm{KCl}$ ); tratar com água oxigenada $6 \%$ para bloquear a peroxidase endógena; lavar três vezes, cinco minutos cada, com PBT; digerir com

\begin{tabular}{cc} 
Tabela & citrato de sódio (SSC) \\
\hline Conteúdo de SSC & {$[\mathrm{Na}+]$} \\
\hline $20 \mathrm{x}$ & 3,3 \\
$10 \mathrm{x}$ & 1,65 \\
$5 \mathrm{x}$ & 0,825 \\
$2 \mathrm{x}$ & 0,33 \\
$1 \mathrm{x}$ & 0,165 \\
$0,1 \mathrm{x}$ & 0,0165 \\
\hline
\end{tabular}


proteinase $\mathrm{K}(10 \mu \mathrm{g} / \mathrm{ml}$, por exemplo) (Invitrogen, Carlsbad, USA) e a seguir incubar com uma solução de glicina $(0,027 \mathrm{M})$ (Sigma, Alemanha); lavar três vezes, cinco minutos cada, com PBT; dispor as lâminas para pré-hibridização, em conjunto de quatro, em saquinhos que serão preenchidos com solução de hibridização (formamida 50\%, SDS 1\%, heparina [50 $\mu \mathrm{g} / \mathrm{ml}]$ ), RNA yeast $(50 \mu \mathrm{g} / \mathrm{ml})$ e a ribossonda $(\sim 0,2 \mu \mathrm{g} / \mathrm{ml})$. Os sacos são selados pela ação do calor ${ }^{(23)}$ e levados ao hibridizador durante uma hora à temperatura adequada $\left(50-70^{\circ} \mathrm{C}\right)$, e então a sonda é acrescida numa concentração aproximada de $200 \mathrm{ng} / \mathrm{ml}$. No segundo dia, abrir os saquinhos e colocar as lâminas em porta-lâmina, lavar com solução de formamida (50\% formamida, SDS 1\%, 6x SSC [pH 4,5] [20 x SSC = 3,0 $\mathrm{M} \mathrm{NaCl}, 0,3 \mathrm{M}$ citrato de sódio]) três vezes de dez minutos cada, à temperatura em que foi realizada a hibridização; lavar com o tampão TBST $(0,1 \mathrm{~mol} / \mathrm{L}$ Tris-HCl [pH 7,5], 0,15 mol/L $\mathrm{NaCl}, 0,05 \%$ Tween 20); bloquear com soro fetal bovino $5 \%$ (Cultilab, Brasil) por uma hora à temperatura ambiente e dispor as lâminas em saquinhos, como no dia anterior, que serão preenchidos com a solução contendo o anticorpo antidigoxigenina-AP e depois selados e levados ao agitador a $4^{\circ} \mathrm{C}$, onde ficarão durante 18 horas. No terceiro dia, abrir os saquinhos e lavar as lâminas com solução tampão TBST [1 $\mathrm{x}$ TBS (10 x TBS = 1,37 M NaCl, 0,027 M KCl, 0,25 M Tris- $\mathrm{HCl}$ $(\mathrm{pH} 7,5)), 1 \%$ Tween 20] e colocar as lâminas em contato com a solução de detecção nitroazul de tetrazólio/5-bromo4-cloro-3-indolil fosfato (NBT/BCIP) (Roche, Alemanha) à temperatura ambiente. $\mathrm{O}$ sinal poderá ser visualizado a partir de duas horas após o início da reação.

Alterações desse protocolo com o objetivo de padronizar a reação para uma determinada amostra são viáveis e dependem principalmente do tipo de tecido a ser analisado e do tamanho da sonda. Em geral, sondas grandes (> 800bp) necessitam de maiores estringência, tempo de digestão com proteinase $\mathrm{K}$, ou maior concentração, e temperatura de hibridização.

\section{Aplicações e problemas do método}

A reação de hibridização in situ, de uma maneira geral, pode ser aplicada tanto ao diagnóstico de diferentes doenças, como a diferentes áreas de pesquisa, utilizando sondas radioativas ou não $0^{(14,24)}$. Essas aplicações muitas vezes envolvem variações da técnica, como a fluorescence in situ hybridization (FISH) e a PCR in situ.

Em patologia, a reação de hibridização in situ utilizando sonda não-radioativa é aplicada principalmente para: detec- tar RNA de origem viral ou bacteriana; proporcionar informação morfológica e observar expressão gênica (mRNA), por exemplo, quando a expressão protéica for baixa ou quando a proteína é exportada rapidamente da célula dificultando sua detecção por imuno-histoquímica; verificar a possibilidade da ação de mecanismos de controle póstranscricional $(9,14,24)$. Por exemplo, a hibridização de mRNA viral em fígado tem ajudado a compreender a complexidade da infecção causada por hepatite $B^{(26)}$. Com a utilização de sondas para DNA ou com seqüências curtas de nucleotídeos suas aplicações são ainda mais extensas, podendo-se usar inclusive sondas cromossômicas para observação de aneuploidia ou estudo de doenças genéticas ${ }^{(18)}$. Por permitir a localização celular/tecidual dos ácidos nucléicos, a ISH tem grande potencial ${ }^{(11)}$. Os resultados, analisados do ponto de vista morfológico, podem trazer uma grande contribuição para identificar transcritos de oncogenes, citocinas, hormônios, entre outros, num contexto celular e tecidual. Além disso, quando em associação com a imuno-histoquímica, as ribossondas podem ser usadas para estudar, por exemplo, infecções virais e diferenciar infecções virais produtivas de não-produtivas ${ }^{(4)}$.

Um dos maiores problemas da ISH é a distinção entre o sinal específico e a coloração de fundo, já que fatores como concentração da sonda, digestão enzimática, lavagem póshibridização, entre outros, podem determinar sua ligação com componentes do tecido, como nervos, epitélio glandular e colágeno, por exemplo. Assim o conhecimento da histologia e a interpretação crítica do padrão de marcação são essenciais.

Outra questão a ser reforçada é a utilização da técnica descrita na rotina de um laboratório de patologia. A técnica que descrevemos para material congelado pode ser modificada para tecido emblocado em parafina. Devido à importância desses arquivos, mantidos em laboratório de patologia, existe um grande interesse por parte dos patologistas em padronizar a técnica de ISH para utilizá-la na rotina de um laboratório de patologia. Em geral pode-se dizer que a detecção de transcritos é possível quando eles estão presentes em grande quantidade. Alguns artigos já foram escritos sobre a utilização de ISH em tecido parafina$\mathrm{do}^{(13,17)}$. Porém, deve-se ter sempre em mente a facilidade de degradação do mRNA, entre outros fatores técnicos que podem interferir na sua detecção. Esses fatores são especialmente importantes quando se considera a utilização da ISH em tecido descalcificado(1). 
Como exemplo da deteç̧ão de transcritos (mRNA) pela técnica de hibridização in situ, a Figura 2 mostra sinal obtido com as sondas anti-senso para transcritos dos genes PITX1 (2AB e 2B), SHH (2C) e WNT5A (2D), e a ausência de sinal para as sondas senso PITX1 (2E) e WNT5A (2F), nos mesmos tecidos. Pode-se observar que as sondas PITX1 e SHH estão presentes apenas no epitélio e a sonda WNT5A, apenas no mesênquima do embrião de camundongo em desenvolvimento. Dependendo do estudo ou da pesquisa que se deseja realizar, técnicas adicionais, como imuno-histoquímica, poderão ser utilizadas. Na Figura $2 \mathrm{~A}$ o objetivo da marcação é observar a expressão do gene PITX1 em tecido congelado não-tumoral, enquanto na Figura $2 \mathrm{~B}$ pode-se observar, comparativamente, a expressão do mesmo gene no carcinoma epidermóide de boca.

Nas Figuras $2 \mathrm{C}$ e 2D, utiliza-se a técnica da ISH para estudo do desenvolvimento do palato em camundongos. Nesse caso, é possível sugerir se os genes SHH e WNT5A participam do desenvolvimento do palato desses animais.

Exemplos de controle negativo da marcação ISH são apresentados nas Figuras 2E e $2 \mathrm{~F}$.

\section{Perspectivas}

A reação de hibridização in situ para detecção de mRNA vem concretamente se estabelecendo como uma técnica complementar à rotina histopatológica. Além da possibilidade de visualização, em célula ou tecido, da expressão de um ou mais mRNA, a técnica pode ser utilizada para identificação de vários microorganismos, para citogenética e para diversas aplicações em pesquisa. Além disso, a possibilidade de combinação dessa técnica com metodologias consagradas, como a imuno-histoquímica, pode contribuir ainda mais para a rotina de diagnóstico e para a obtenção de respostas quanto à patogênese de muitas doenças. Concluindo, a técnica ISH com certeza pode ser incorporada com vantagens em laboratórios de patologia e pesquisa.

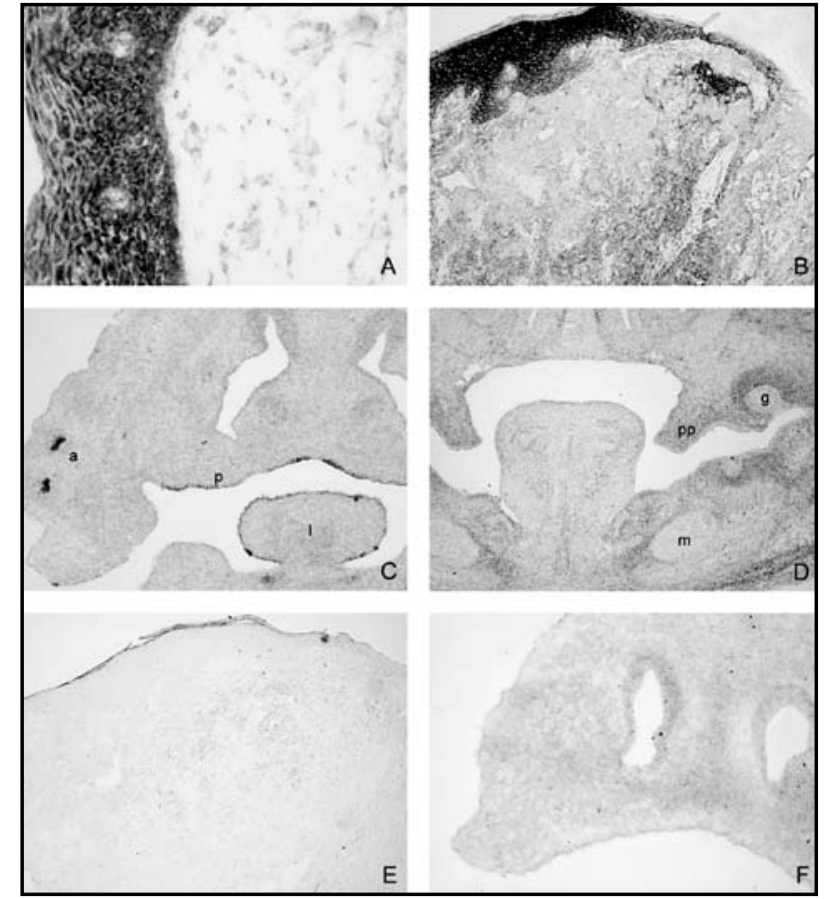

Figura 2 - Em A, observamos epitélio não-tumoral onde todas as camadas estão apresentando sinal para a sonda anti-senso PITX1. 0 mesmo tipo de sinal pode ser encontrado em $B$, sendo que o sinal para a sonda é muito menor no carcinoma epidermóide que se encontra infiltrando o tecido conjuntivo subjacente. Em embrião de camundongo de 13 dias (C e D) a sonda anti-senso SHH (C) mostra sinal no epitélio do palato (p), língua (I) e anexo cutâneo (a), em desenvolvimento. Em D, a sonda WNT5A apresenta sinal no processo palatino em elevação (pp), ao redor do germe dentário ( $g$ ) e no mesênquima ao redor da cartilagem de Merkel (m). Em E e F, mostra-se a ausência de sinal obtida com o uso da sonda senso (controle negativo), respectivamente para PITX1 e WNT5A

\section{Agradecimentos}

Agradecemos à disciplina de Cirurgia de Cabeça e Pescoço do Hospital das Clínicas da Faculdade de Medicina da USP por ter gentilmente cedido os espécimes para os experimentos de hibridização in situ; aos alunos do Laboratório de Patologia Molecular da FOUSP pela leitura crítica deste trabalho; à FAPESP (projetos 97/13228-5, 01/13644-4, 02/11220-7, 02/12696-5) e ao CNPq (processo 473350/03-3) pelo fomento das pesquisas em nosso laboratório.

\section{Referências}

I. ARBER, J. M. et al. The effect of decalcification on in situ hybridization. Mod Pathol, v. 10, n. 10, p. 1009-14, 1997.

2. BASYUK, E., BERTRAND, E., JOURNOT, L. Alkaline fixation drastically improves the signal of in situ hybridization. Nucleic Acids Res, v. 28, n. 10, p. E46, 2000.
3. BELIN, D. The use of RNA probes for the analysis of gene expression. Mol Biotechnol, v. 7, n. 2, p. 153-63, 1997.

4. BROWN, C. In situ hybridization with riboprobes: an overview for veterinary pathologists. Vet Pathol, v. 35, n. 3, p. 159-67, 1998. 
5. CORPUT, M.P.C. et al. Sensitive mRNA detection by fluorescence in situ hybridization using horseradish peroxidase-labeled oligonucleotides and tyramide signal amplification. J Histochem Cytochem, v. 46, p. 1249-59, 1998.

6. COX, K. H. et al. Detection of mRNAs in sea urchin embryos by in situ hybridization using asymmetric RNA probes. Dev Biol, v. IOI, p. 485-502, 1984.

7. GALL, J. G., PARDUE, M. G. Formation and detection of RNADNA hybrid molecules in cytological preparation. Proc Nat Acad Sci, v. 63, p. 378-83, 1969.

8. GANDRILLON, O. F. et al. A rapid and convenient method to prepare DIG-labelled RNA probes for use in nonradioactive in situ hybridization. Mol Cell Probes, v. 10, n. I, p. $51-5,1996$.

9. HEINKHEIMMO, K.; HAPPONEN, R. P. In situ hybridization using single-stranded antisense RNA probes in oral pathology research. Proc Finn Dent Soc, v. 87, n. 2, p. 245-57, 1991.

I0. NATIONAL CENTER FOR BIOTECHNOLOGY INFORMATION. GenBank. http://www.ncbi.nlm.nih.gov/ Genbank/index.html; acesso em 23 jun. 2006

I I. HICKS, D. G. et al. In situ hybridization in the pathology laboratory: general principles, automation, and emerging research applications for tissue-based studies of gene expression. J Mol Histol, v. 35, p. 595-60I, 2004

I2.JIN, L.; LLOYD, R.V. In situ hybridization: methods and applications. J Clin Lab Anal, v. I I, p. 2-9, 1997.

13. LEWIS, F. N. J. et al. Unlocking the archive: gene expression in paraffin-embedded tissue.J Pathol, v. 195, n. I, p. 66-7I, 2001.

14. McNICOL, A. M.; FARQUHARSON, M. A. In situ hybridization and its diagnostic applications in pathology. J Pathol, v. 182, p. 250-6I, 1997.

15. MELTON, D. A. et al. Efficient in vitro synthesis of biologically active RNA and DNA probes from plasmids containing bacteriophage SP6 promoter. Nucleic Acids Res, v. 12, p. 7035-56, 1984.

16. MURAKAMI, T. et al. A novel method for detecting HIV-I by non-radioactive in situ hybridization: application of a peptide nucleic acid probe and catalyzed signal amplification.J Pathol, v. 194, p. | 30-5, 200 |
17. NAKAJIMA, N. et al. In situ hybridization AT-tailing with catalyzed signal amplification for sensitive and specific in situ detection of human immunodeficiency virus-I mRNA in formalinfixed and paraffin-embedded tissues. Am J Pathol, v. 162, p. $381-9,2003$

18. SAXBY, A. J. et al. Assessment of HER-2 status in pancreatic adenocarcinoma: correlation of immunohistochemistry, quantitative real-time PCR, and FISH with aneuploidy and survival. Am J Surg Pathol, v. 29, n. 9, p. I I 25-34, 2005.

19. SOLER, C. et al. Influence of fixation on human papillomavirus DNA detection in frozen and embedded paraffin lesions by in situ hybridization with biotinylated probes. Pathol Res Pract, v. I 88, n. 8, p. $1018-27,1992$.

20.TBAKHI, A. et al. Fixation conditions for DNA and RNA in situ hybridization: a reassessment of molecular morphology dogma. Am J Pathol, v. I 52, n. I, p. 35-4I, 1998.

21. TREMBLEAU, A.; ROCHE, D.; CALAS, A. Combination of non-radioactive and radioactive in situ hybridization with immunohistochemistry: a new method allowing the simultaneous detection of two mRNAs and one antigen in the same brain tissue section. J Histochem Cytochem, v. 4I, n. 4, p. 489-98, 1993.

22. URIELI-SHOVAL, S. et al. Preservation of RNA for in situ hybridization: Carnoy's versus formaldehyde fixation. J Histochem Cytochem, v. 40, n. 12, p. 1879-85, 1992.

23.VALENZUELA-DÍAZ, F. R. et al. Substituição de filme laminado por filme coextrudado em técnica de biologia molecular. $8^{\circ}$ Simposium Latino-Americano de Polímeros. Libro de Resúmenes del SLAT, p. 302-3, 2002.

24. WARFORD, A.; LAUDER, I. In situ hybridization in perspective. J Clin Pathol, v. 44, p. 177-81, 1991.

25.WILKINSON, D. G. RNA detection using non-radioactive in situ hybridization. Curr Opin Biotechnol, v. 6, n. I, p. 20-3, 1995.

26. WU, P. C. et al. Hepatic expression of hepatitis $B$ virus genome in chronic hepatitis B virus infection. Am J Clin Pathol, v. I05, n. I, p. 87-95, 1996.

27.YOUNG,W.S. III. Simultaneous use of digoxigenin-and radiolabeled oligodeoxyribonucleotide probes for hybridization histochemistry. Neuropeptides, v. I3, p. 27I -5, 1989. 